\title{
International Primary Care Respiratory Group (IPCRG) Guidelines: Dissemination and Implementation - a proposed course of action
}

\author{
Ron Tomlins*
}

Discipline of General Practice, Western Clinical School, University of Sydney, Australia

Received 19 November 2005; accepted 23 November 2005

\begin{abstract}
KEYWORDS
Guideline;

Respiratory diseases;

Primary care;

General practice;

Dissemination;

Implementation

Summary There is growing evidence that good implemsntation onevidencebased guidelines can result in improvement in heatch ourcomes. This paper on Dissemination and Implementation Anstitutes ti e hinal paper of the IPCRG Guidelines on the managemari ic $T$ (4) or Ic iespiratory diseases in primary care. It highlights the histolical cievelopment of these suigelines following the formation I the III Enational Primary Care Ailwdy (iicup (IPAG) in 2001 together with its aissemination and impleinentation subgroup, and the subsequent transfer of this disseminatior and inplementation role to the IPCRG. It covers the main factors vithin the IPCRG workplan, including the issues of governance, launch, dissemination, implementation, and evaluation.

(c) 2005 General Practice Airways Group. Published by Elsevier Ltd. All rights reserved.
\end{abstract}

Despite our knowledge of effective treatments for common chronic respiratory illnesses, people with these respiratory illnesses remain sub-optimally managed [1]. The availability of national and international guidelines provides healthcare professionals with evidence-based recommendations for diagnosis and management. There is growing evidence that implementation of evidence-based guidelines can result in improvement of health outcomes [2-6] or in improvement in the confidence of health professionals to manage care in line with best

* PO Box 436, Cherrybrook, NSW 2126, Australia. Tel.: +612 94840050.

E-mail address: rtomlins@ozemail.com.au. available evidence [7]. There is also evidence of failure to implement, and barriers to the implementation of, cost-effective health interventions in both high-income and low-income countries [7-10]. A number of reviews have explored effective ways to promote the uptake of evidence-based interventions [11-15].

The International Primary Care Airways Group (IPAG) was formed in 2001 by Primary Care specialists with strong links to primary care respiratory groups and global primary care groups, working in close collaboration with public health officials from the World Health Organisation (WHO), and respiratory specialists in the European Academy of Allergology and Clinical Immunology $(E A A C l)$, the Global Initiative for Asthma (GINA), 
the Global Initiative for Chronic Obstructive Lung Disease (GOLD), and the Allergic Rhinitis and its Impact on Asthma Initiative (ARIA). Their goal was to develop guideline materials written by, and produced for, primary care doctors, which would be appropriate to primary care diagnosis and treatment of chronic respiratory diseases [16].

The motivation for the IPAG project flowed from the recognition that, globally, primary care clinicians treat the vast majority of patients with chronic airways diseases. However, international evidence-based practice guidelines are often complicated and recommend the use of resources which are not always available in the primary care setting.

Within the IPAG project workplan, guideline dissemination and implementation were seen as critical elements of guidelines development, and it was realized that a global program of dissemination and implementation would be best carried out through existing global, regional, and national primary care societies and other interested groups. A dissemination and implementation working group comprising Dr Ron Neville (chair) Dr. Karin Lisspers, Dr. Svein Hoegh Henrichsen, Dr. Ivo Smeele, Prof. Martyn Partridge (GINA Executive Member), Prof. Richard Beasley (GINA Executive Member) and Dr. Nikolai Khaltaev (WHO) identified a numbe of principles to underpin guideline disseminetion and implementation. These $v$ tre-

- Disse nination and implamentation siralesties shoula be evidence-based

- There is a growing body of evidence to support continuous quality improvement (US terminology) or audit projects (European). Patient outcomes can be improved if healthcare professionals are actively involved in projects to link guidelines with patient-specific feedback.

- There is a need for a repository or 'toolkit' of materials to help healthcare professionals deliver good quality care for people with asthma in line with guidelines.

- A co-ordinated series of educational initiatives aimed at healthcare professionals and patients is required for successful implementation. These initiatives are preliminary activities to prepare professionals and to raise public awareness.

- While barriers to implementation may be local, there are good examples from many different environments of how the problems of implementation can be overcome. Healthcare professionals can offer each other mutual support.

Subsequently, the dissemination and implementation role for the guidelines was transferred to the dissemination and implementation subgroup of the International Primary Care Respiratory Group (IPCRG) chaired by $\mathrm{Dr}$ Ron Tomlins, with the members of the IPAG working group continuing to be engaged. Dr Barbara Yawn contributed to the workplan. The IPCRG workplan is reproduced here as an example of how such an international program could work:

- Governance

- Identify a Steering Group of Professionals and Patient Representatives to co-ordinate activities (including members of the GINA Dissemination and Implementation Strategy Group).

- Engage one patient group to join collaboration (for example EFA, perhaps with support from the Global Asthma Coalition).

- Establish a sponsorship policy to provide funding for the dissemination and implementation of guidelines. This may involve international funding to underpin IPCRG activities, and national or local funding to support national or local implementation. The policy should take ascount: Cf editorial independence, ovinersh. or intellectual preped v and áppropriate mechanisms for the (i.censing of IPAC/IPCRG materials consistent with pritices relating to pharmaceutical fecmpany sponsorship of educational activities applying in individual countries.

- The Steering Group will undertake continuing review of the dissemination and implementation process and will adapt strategies to fit prevailing circumstances.

- Launch

- Produce a draft pocket-sized Primary Care version of the integrated GINA, GOLD and ARIA guidelines based around attainment of these outcomes.

- Translate into the major languages of Europe and make available for 'download' on the Internet.

- Publish guidelines in an appropriate journal (Primary Care Respiratory Journal).

- Launch guidelines at IPCRG Conference in Melbourne in February 2004.

- Where appropriate, consider national launches of guidelines.

- Dissemination

- Invite comment and criticism from national and international respiratory professional organisations with a view to seeking endorsement, preferably before the launch.

- Invite comment and criticism from key patient associations. 
- Develop a 'model' communications plan to support dissemination by national bodies and patient groups.

- Establish (through IPCRG) a panel of International GP speakers to facilitate local and national guidelines meetings.

- Develop educational resources (including webenabled interactive products) to facilitate the implementation of guidelines.

- Implementation

- Develop a 'model' implementation plan to support implementation by national bodies and patient groups.

- Work with the pharmaceutical industry and national member bodies of IPRCG to facilitate the local implementation of guidelines, in accordance with IPCRG policy. This may include the national member body developing an implementation plan with the pharmaceutical industry and undertaking evaluation of the implementation.

- Establish a forum on the Internet for the sharing of ideas and to exchange news of successful projects.

- Develop standards-based electronic tools to support the incorporation of guidelines into prescribing programs or the recording of data to enhance evaluation.

- Provide a peer-group sunport soiviea to clinicians in individial couritres wishing to help rum arditlpar hages or to reost land publish on their findings.

- Evaluation

- Identify a set of outcome measures relevant to primary care.

- Set up an Internet-based 'toolkit' of audit and 'quality of care' materials.

- The existing 'International Asthma Quality of Care' (www.iaqoc.com) site could be adapted for this purpose.

- Encourage professionals involved in continuous quality improvement or audit projects to report their findings to the ERS Primary Care Symposium or other suitable venues.

- Run an Internet-based international audit and feedback service for health care professionals wishing to compare their own management of asthma patients with colleagues nationally and internationally. (The IAQOC project could be developed to meet this aim.)

The IPCRG workplan has yet to be fully implemented.

Guideline development and implementation in a primary care setting is an active area for research. There is increasing awareness of the crucial role for funding agencies in structuring incentives for delivery of evidence-based care [7,17-19] and in gaining an understanding of the cultural or attitudinal factors that influence healthcare providers, patients and their carers in the attainment of optimal health outcomes [20-28]. Perhaps the most interesting areas for exploration are the 'core' primary care areas of continuity of care [29], the management of co-morbidity $[30,31]$ and integration with other health services [32]. The evidence is starting to accumulate, from both cross-national and intra-national studies, that primary care helps prevent illness and death and is associated with a more equitable distribution of health within populations, thereby suggesting ways to improve overall health and reduce differences in health across major population sub-groups [33].

\section{References}

[1] Partridge MR, van der Molen T, Myrseth SE, Busse W. Asthma patients remain poorly controlled dospite being prescribed maintenance treatrent EUI Ras? J 2005; 26(Suppl 49).

[2] Glasgow N J, Fonson, A-1., Yates R, Beilby J, Dugdale P. P. (ar Ive asthıma care in childhood: general practice based randomised contrilled cral. BMJ 2003;327:659-65.

[3] Bassar.d JP, Priori S, Tendera M. Evidence-based vs. 'im precsionist' medicine: how best to implement guidelines. Eur Heart J 2005;26:1155-8.

[4] Brand C, Landgreen F, Hutchinson A, Jones C, Macgregor L, Campbell D. Clinical practice guidelines: barriers to durability after effective early implementation. Intern Med J 2005;35:162-9.

[5] Engers AJ, Wensing M, van Tulder MW, et al. Implementation of the Dutch low back pain guideline for general practitioners: a cluster randomized controlled trial. Spine 2005;30:559-600.

[6] Lesho EP, Myers CP, Ott M, Winslow C, Brown JE. Do clinical practice guidelines improve processes or outcomes in primary care? Mil Med 2005;170:243-6.

[7] Zwar NA, Comino EJ, Hasan I, Harris MF. General practitioner views on barriers and facilitators to implementation of the Asthma 3+ Visit Plan. Med J Aust 2005;183:64-7.

[8] Haines A, Kuruvilla S, Borchert M. Bridging the implementation gap between knowledge and action for health. Bull World Health Organ 2004;82:724-31.

[9] Grimshaw J, Eccles M, Tetroe J. Implementing clinical guidelines: current evidence and future implications. Contin Educ Health Prof 2004;24(Suppl 1):S31-7.

[10] Barnes PJ. The size of the problem of managing asthma. Respir Med 2004;98(Suppl B):S4-8.

[11] Partridge MR et al., on behalf of the GINA Dissemination Committee. Dissemination and implementation of asthma guidelines. 2002. Available at http://www.ginasthma. com/Reportltem. asp?!1=2\&l2=2\&intld=96.

[12] Grol R, Grimshaw J. From evidence to best practice: effective implementation of change in patients' care. Lancet 2003;362:1225-30. 
[13] Lanier DC, Roland M, Burstin H, Knottnerus JA Doctor performance and public accountability. Lancet 2003;362:1404-8.

[14] Sheldon TA, Cullum N, Dawsons D, et al. What's the evidence that NICE guidance has been implemented? Results from a national evaluation using time series analysis, audit of patients' notes, and interviews. Brit Med J 2004;329:999-1007.

[15] Volmink J, Siegfried N, Robertson K, Gülmezoglu AM. Research synthesis and dissemination as a bridge to knowledge management: the Cochrane Collaboration. Bull World Health Organisation 2004;82:778-83.

[16] For more information on IPAG, see www.ipagguide.com/.

[17] Checkland K, Harrison S. Policy implementation in practice: the case of national service frameworks in general practice. J Tissue Viability 2004;14:133-6.

[18] Ovretveit J. Formulating a health quality improvement strategy for a developing country. Int J Health Care Qual Assur Inc Leadersh Health Serv 2004;17:368-76.

[19] Vaca J, Peralta H, Greseley L, et al. DOTS implementation in a middle-income country: development and evaluation of a novel approach. Int J Tuberc Lung Dis 2005;9:521-7.

[20] Harris GS, Shearer AG. Beliefs that support the behavior of people with asthma: a qualitative investigation. J Asthma 2001;38:427-34.

[21] Bailie RS, Si D, Robinson GW, Togni SJ, d'Abbs PHN. Multifaceted health-service intervention in remote Aboriginal communities: 3-year follow-up of the impact on diabetes care. Med J Aust 2004;181:195-200.

[22] Greenway-Crombie A, Conners A-M, Snell T, Oerlemans M. Development of a rural asthma management model. Rural and Remote Health 3 (online), 2003: 149. Available from: http://rrh.deakin.edu.au.

[23] Hagaman JT, Yurkowski P, Trott A, Rouan GIM Ge:zing physicians to make 'the swi-cn' the rele o: clinical guidelines in the "manigenent s. community-acquired

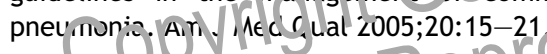

[24] Hysong SJ, Best RG, Pugh JA, Moore FI. Using guidelines and reminders. Not of one mind: mental models of clinical practice guidelines in the Veterans Health Administration. Health Serv Res 2005;40:829-48.

[25] Litt J. Smoking and GPs: time to cough up. Aust Fam Phys 2005;34:425-9.

[26] Joseph AM, Arikian NJ, An LC, Nugent SM, Sloan RJ, Pieper CF. Results of a randomized controlled trial of intervention to implement smoking cessation guidelines in Veterans Affairs medical centers: increased use of medications without cessation benefit. Med Care 2004;42: 1100-10.

[27] McKinlay E, McLeod D, Dowell A, Marshall C. Clinical practice guidelines' development and use in New Zealand: an evolving process. NZ Med J 2004;117:1199.

[28] Michie S, Johnston M, Abraham C, Lawton R, Parker $D$, Walker A. Making psychological theory useful for implementing evidence based practice: a consensus approach. Qual Saf Health Care 2005;14:26-33.

[29] Haggerty JL, Reid RJ, Freeman GK, Starfield BH, Adair CE, McKendry R. Continuity of care: a multidisciplinary review. Brit Med J 2005;327:1219-21.

[30] Boyd CM, Darer J, Boult C, Fried LP, Boult L, Wu AW. Clinical practice guidelines and quality of care for older patients with multiple comorbid diseases. J Am Med Assoc 2005;294:716-24.

[31] Starfield B, Lemke KW, Bernbardt T, Foley SS, Forrest CB, Weiner JP. Comorbidity: implications for the importance of primary care in 'case' management. Ann Fam Med 2003;1:8-14.

[32] Briggs CJ, Capdegella P, COrne-P Strategies for integrating primary carla servic es in middle- and low-income countries: effects on performance, costs and patient outcomes (review). The foch ane Database of Systematic Reviews $2001 \cdot(+)$

[33] ; a field B, Shui L, Macinko J. The Millbank Quart 2005;83:457.

Available online at www.sciencedirect.com

science d Direct.

\section{Available online at http://www.thepcrj.com}

